\title{
DESCRIPTION OF THE EVIAVE METHODOLOGY FOR ENVIRONMENTAL DIAGNOSIS OF MUNICIPAL WASTE LANDFILLS
}

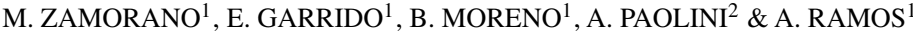 \\ ${ }^{1}$ Escuela Técnica Superior de Ingenieros de Caminos, Canales y Puertos, Department of Civil Engineering, \\ University of Granada, Spain. \\ ${ }^{2}$ Decanato de Ingeniería Civil, Departamento de Hidráulica y Sanitaria, Universidad Centrocidental Lisandro Alvarado, \\ Barquisimeto, Venezuela.
}

\begin{abstract}
In Europe, a Council Directive passed in 1999 provided for the regulation of waste disposal in landfills. This was a specific piece of legislation aimed at environmental control of new and currently operational installations. As a result, it has become necessary to adapt currently operational release points to make them compatible with the new legislation. This new situation has obliged the different environmental organisations to carry out a stocktaking of release points in order to draw up a conditioning plan or a closing plan in accordance with the directive. The present study describes a new methodology by which environmental diagnosis of landfill sites may be carried out, involving the formulation of environmental indexes that give information about the potential environmental problems of currently operational landfills. The indexes provide information related to the location, design and operation in order to help draw up action plans for the conditioning or closure of the landfill site and to prioritise the order of actions required.

Keywords: environmental impact, environmental indexes, landfill, pollution, waste management.
\end{abstract}

\section{INTRODUCTION}

The increasing quantities, inappropriate treatment and final disposal of waste can result in negative impacts to the public health and to the environment [1-3] and also result in social and environmental effects [4]. The damage to the environment due to poor waste management can be avoided by implementing environmentally sensitive waste management techniques involving minimisation, composting, recycling, reuse and waste-to-energy programmes [5, 6]. However, solid waste disposal in landfills remains the usual method of disposal in a vast majority of cases $[3,7,8]$.

Landfills have been defined as the engineered deposits of waste onto and into land in such a way that pollution or harm to the environment is prevented and, through restoration, the land may be made available for other uses [9]. Landfills were initiated largely as a result of the need to protect the environment and society from the adverse impacts of alternative methods of refuse disposal such as open-air burning, open-pit dumping and ocean dumping [7, 10].

Although landfills have eliminated some impacts of old practices, new problems have arisen, primarily due to gas and leachate formation. Besides potential health hazards, these concerns include fires and explosions [7, 11], vegetation damage [10, 12, 13], unpleasant odours [7, 8, 14, 15], landfill settlement $[16,17]$, ground and surface water pollution [18-20], air pollution [15, 21] and global warming [22-24].

\subsection{The impact of the European Landfill Directive}

The European Union Directive 31/1999 for controlling the landfilling of waste was under discussion for many years prior to its publication in April 1999. The overall aim of the directive is to prevent or reduce, as far as possible, any negative impacts on human health or the environment due to the landfilling of waste. In particular, the directive is concerned with preventing the pollution of 
surface and groundwater, soil and air. To meet these objectives, several measures are required that aim at improving the design, operation and management of landfills and also at restricting the types of wastes that are allowed to be landfilled.

The landfill directive was due to be incorporated into the national law of each EU member state by July 2001. Some examples of countries implementing the directive are Spain [3], the United Kingdom $[25,26]$ and Finland [27].

The member states are obliged to take measures to ensure that landfills that had already been granted a permit or were already in operation when the directive came into force do not continue to operate unless the requirements are met within a maximum of eight years after the date of the legislation. In consequence, environmental organisations have been obliged to carry out a stocktaking of release points located in their territory in order to draw up a conditioning plan or a closing plan for each site, depending on the environmental problems found in each case. These plans need to include the specific permission conditions listed in the directive and to outline any corrective measures, which the operators consider necessary to comply with the directive requirements [28]. In the specific case of Spain, the deadline for the conditioning plans was the end of 2002; however, it has been shown that $52 \%$ of landfills do not yet have a plan [3].

1.2 Methodologies for evaluating the environmental impact of waste landfills

The first step in applying the directive is to inspect the landfill sites and to study their environmental impact. This in turn involves carrying out an environmental diagnosis of the landfill to identify the various problems. A number of authors have worked on different methods for evaluating the environmental impact in the design plans for new landfills [29,30], and methodologies have also been developed to study public opinion with regard to the siting of new landfills [31]. These studies are of limited relevance to our research, since we are concerned with landfills that are currently in operation. Nevertheless, on the basis of these methods, further methodologies have been developed to carry out environmental diagnosis in operational facilities with the aim of resolving particular problems in certain provinces or groups of municipalities [19, 32].

In most cases, these methods involve stocktaking of local natural phenomena in order to compile lists of the impacts on the landfills where monitoring was undertaken, but the sphere of application is limited. Such methods make it possible to compare landfills environmentally but not to take decisions about their control, closing, sealing or recovering. There is a general lack of physical medium studies and all assessments relate to the release point, without taking into account the characteristics of the area in which the landfill is situated [3].

Accordingly, we have developed a new methodology with the objective of providing sufficient data to determine the environmental problems generated by waste landfills and to control their operational state. The methodology has already been applied to a large number of landfills, and some changes are being incorporated to correct specific shortcomings and to create softwares using an intelligent system based on fuzzy inference. The objective of this paper is to describe the final methodology, named EVIAVE.

\section{METHODOLOGY DESCRIPTION}

The methodology is based on the use of environmental indexes, which are explained in the following subsections, designed to provide quantitative assessment of the environmental interaction between the release point and the potentially affected environmental elements (surface water, groundwater, atmosphere, soil and health). In addition, assessment is made of the environmental value of each 
environmental element taken into account, as well as of the operational state of the landfill from the environmental point of view [2,3].

The methodology was developed first only for uncontrolled landfills but was later altered to apply in the case of controlled landfills too. Co-disposal of municipal, inert and hazardous wastes has been considered in the variable 'waste and organic matter types'. So EVIAVE may be applied to municipal solid waste landfills classified as non-hazardous by the Directive 31/1999 [28] and co-disposal of municipal, some hazardous and inert wastes. Territorial application of the methodology may include countries in the European Union and any other country where a similar legislation exists, or indeed where there is no legislation or the legislation is less prescriptive than this directive [3].

\subsection{Environmental Landfill Impact Index}

The methodology obtains a general index called the 'Environmental Landfill Impact Index' (ELI) [2, 3]. This index characterises the overall environmental state of the landfill, obtaining values between 0 and 25 with classifications of 'very high', 'high', 'average', 'low' and 'very low' (Table 1). It is expressed by eqn (1), where $\mathrm{ERI}_{i}$ is the Environmental Risk Index for each environmental element.

$$
\mathrm{ELI}=\sum_{i=1}^{i=5} \mathrm{ERI}_{i} .
$$

Applied to different landfills in the same study area, the ELI can be used to draw up lists of priority actions. Landfills with greater ELI values would receive higher priority of action since they pose greater environmental problems.

\subsection{Environmental Risk Index}

The 'Environmental Risk Index' (ERI) determines the environmental impact potential for each environmental element, reflecting whether or not interaction exists between the release point or landfill and the characteristics of the environment $[2,3]$. For each landfill, the ERI indicates which environmental element or elements are most affected by the presence of wastes, making it possible to determine the extent of deterioration in each case.

The index is expressed by eqn (2), where $\mathrm{Pbc}_{i}$ is the probability of contamination and $\mathrm{eV}_{i}$ is the environmental value, both for each environmental element $(i)$. The index obtains values between 0 and 5 with classifications of 'very high', 'high', 'average', 'low' and 'very low' (Table 1).

$$
\mathrm{ERI}_{i}=\mathrm{Pbc}_{i} \times \mathrm{eV}_{i} .
$$

\begin{tabular}{|c|c|c|c|c|}
\hline Very low & Low & Average & High & Very high \\
\hline$\leq \mathrm{ELI}<5$ & $5 \leq \mathrm{ELI}<10$ & $10 \leq \mathrm{ELI}<15$ & $15 \leq \mathrm{ELI}<20$ & $20 \leq \mathrm{ELI}$ \\
\hline $0 \leq \mathrm{ERI}_{i}<1$ & $1 \leq \mathrm{ERI}_{i}<2$ & $2 \leq \mathrm{ERI}_{i}<3$ & $3 \leq \mathrm{ERI}_{i}<4$ & $4 \leq \mathrm{ERI}_{i} \leq 5$ \\
\hline $1 \leq \mathrm{eV}_{i}<1.8$ & $1.8 \leq \mathrm{eV}_{i}<2.6$ & $2.6 \leq \mathrm{eV}_{i}<3.4$ & $3.4 \leq \mathrm{eV}_{i}<4.2$ & $4.2 \leq \mathrm{eV}_{i} \leq 5$ \\
\hline $0 \leq \mathrm{Pbc}_{i}<0.2$ & $0.2 \leq \mathrm{Pbc}_{i}<0.4$ & $0.4 \leq \mathrm{Pbc}_{i}<0.6$ & $0.6 \leq \mathrm{Pbc}_{i}<0.8$ & $0.8 \leq \mathrm{Pbc}_{i} \leq 1$ \\
\hline $0 \leq$ Pbc-s $_{i}<0.2$ & $0.2 \leq \mathrm{Pbc}_{-\mathrm{s}_{i}}<0.4$ & $0.4 \leq \mathrm{Pbc}_{-} \mathrm{s}_{i}<0.6$ & $0.6 \leq \mathrm{Pbc} \mathrm{s}_{i}<0.8$ & $0.8 \leq{\mathrm{Pbc}-\mathrm{S}_{i} \leq 1} \leq 1$ \\
\hline 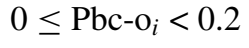 & 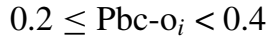 & $0.4 \leq \mathrm{Pbc}-\mathrm{o}_{i}<0.6$ & $0.6 \leq \mathrm{Pbc}-\mathrm{o}_{i}<0.8$ & $0.8 \leq{\mathrm{Pbc}-\mathrm{o}_{i} \leq 1} \leq 1$ \\
\hline
\end{tabular}

Table 1: Classification of different indexes. 
2.3 Probability of contamination

The probability of contamination $(\mathrm{Pbc})$ for each environmental element depends on the scale of operation, as well as waste characteristics and the spread of disposals in the landfill environment $[2,3]$. It may obtain values between 0 and 1 and is classified as 'very high', 'high', 'average', 'low' and 'very low' (Table 1).

In order to assess the contamination possibility, a number of landfill variables are selected for each environmental element. These variables are characteristics of the landfill related to biochemical and physical processes, which directly or indirectly affect the environmental elements. The variables make it possible to quantify the risk of contamination owing to the landfill location and operation. All the variables have a theoretical justification of their state and are based on guidelines established in the European Council Directive 1999/31/EC [28]. Table 2 shows selected variables for each environmental element.

The variables are classified in three groups (Table 3): (1) variables related to the location of the landfill, (2) variables related to the design and operation of the landfill and (2) variables related to both.

The probability of contamination for each environmental element is expressed by eqn (3), where $\mathrm{n}$ is the number of variables affecting each environmental element, $\mathrm{CRI}_{j}$ is the Contamination Risk Index (CRI) for each variable $(j), \mathrm{CRI}_{j_{\text {minimum }}}$ is the minimum value obtained by the CRI for each variable and $\mathrm{CRI}_{j_{\text {maximum }}}$ is the maximum value obtained by the $\mathrm{CRI}$ for each variable.

$$
\mathrm{Pbc}_{i}=\frac{\sum_{j=1}^{j=n} \mathrm{CRI}_{j}-\sum_{j=1}^{j=n} \mathrm{CRI}_{j_{\text {minimum }}}}{\sum_{j=1}^{j=n} \mathrm{CRI}_{j_{\text {maximum }}}-\sum_{j=1}^{j=n} \mathrm{CRI}_{j_{\text {minimum }}}} .
$$

The difference between the probability of contamination and the ERI is that in the first case, the risk of environmental impact of the landfill is calculated without taking into account the environmental value of the area in which the landfill is situated. For example, two landfills might obtain a contamination probability of 0.5 for surface water. However, in one of the landfills the surface water at risk of contamination may have an environmental value of 5 while in the other the value may be only 1 . Although the contamination probability is the same, different CRIs would be obtained for surface water, namely 2.5 and 0.5 , classified as 'average' and 'very low' respectively.

\subsubsection{Contamination Risk Index}

The evaluation of each variable $(j)$ may be obtained by the Contamination Risk Index $\left(\mathrm{CRI}_{j}\right)$ for each variable, whose expression is shown in eqn (4):

$$
\mathrm{CRI}_{j}=C_{j} \times W_{j} .
$$

In this expression, $C_{j}$ is the classification of the variable and provides information on the situation of the release point or the interaction between the disposal processes and the environmental characteristics related to the variable [3]. The range of values may be 1,2,3, 4 or 5 .

$W_{j}$ is the weighting of each variable. Values may be 1 or 2, depending on the relationship between the variable and the concept of 'structural elements' at the release point. The structural elements considered are: the existence of organic matter, humidity and density of the wastes. These three concepts participate in the main biochemical and physical processes produced in the release point and cause production of gas and leachate, affecting all the variables and providing greater weighting to the different landfill variables [3]. For example, the variable 'leachate control' affects the environmental elements of surface water, groundwater and atmosphere, obtaining in each case a weighting of 2 , 
Table 2: The variables and the environmental elements affected.

\begin{tabular}{|c|c|c|c|c|c|}
\hline \multirow[b]{2}{*}{ Variable } & \multicolumn{5}{|c|}{ Environmental element } \\
\hline & $\begin{array}{l}\text { Surface } \\
\text { water }\end{array}$ & Groundwater & Atmosphere & Soil & $\begin{array}{l}\text { Human } \\
\text { health }\end{array}$ \\
\hline Settling of waste & $\mathrm{X}$ & $\mathrm{X}$ & $\mathrm{X}$ & $\mathrm{X}$ & $\mathrm{X}$ \\
\hline Aquifer characteristics & & $\mathrm{X}$ & & & \\
\hline Final covering & $\mathrm{X}$ & $\mathrm{X}$ & $\mathrm{X}$ & $\mathrm{X}$ & $\mathrm{X}$ \\
\hline Compaction & $\mathrm{X}$ & $\mathrm{X}$ & $\mathrm{X}$ & $\mathrm{X}$ & $\mathrm{X}$ \\
\hline Control of gas & & & $\mathrm{X}$ & $\mathrm{X}$ & $\mathrm{X}$ \\
\hline Control of liquid leachate & $\mathrm{X}$ & $X$ & & $\mathrm{X}$ & $\mathrm{X}$ \\
\hline Distance from infrastructure & & & & & $\mathrm{X}$ \\
\hline Distance from surface water mass & $\mathrm{X}$ & & & & \\
\hline Distance from population points & & & & & $\mathrm{X}$ \\
\hline Landfill age & $\mathrm{X}$ & $\mathrm{X}$ & $\mathrm{X}$ & $\mathrm{X}$ & $\mathrm{X}$ \\
\hline Erosion & & & & $\mathrm{X}$ & \\
\hline State of roads in the landfill & & & $\mathrm{X}$ & & \\
\hline $\begin{array}{l}\text { Fault located in proximity } \\
\text { to the landfill }\end{array}$ & & $\mathrm{X}$ & & & \\
\hline Waterproofing of release vessel & $\mathrm{X}$ & $\mathrm{X}$ & & $\mathrm{X}$ & \\
\hline Covering material & $\mathrm{X}$ & $\mathrm{X}$ & $\mathrm{X}$ & $\mathrm{X}$ & $\mathrm{X}$ \\
\hline Slope to surface water & $\mathrm{X}$ & & & & \\
\hline Pluviometry & $\mathrm{X}$ & $\mathrm{X}$ & $\mathrm{X}$ & & \\
\hline $\begin{array}{l}\text { Release point localisation in } \\
\text { floodwater storage volume }\end{array}$ & $\mathrm{X}$ & $\mathrm{X}$ & & $\mathrm{X}$ & \\
\hline $\begin{array}{l}\text { Release point localisation } \\
\text { in surface runoff }\end{array}$ & $\mathrm{X}$ & $\mathrm{X}$ & & & \\
\hline Seismic risk & $\mathrm{X}$ & $\mathrm{X}$ & $\mathrm{X}$ & $\mathrm{X}$ & $\mathrm{X}$ \\
\hline Safety & & & & & $X$ \\
\hline Surface drainage systems & $\mathrm{X}$ & $\mathrm{X}$ & & & \\
\hline Slopes of waste & $\mathrm{X}$ & $\mathrm{X}$ & $\mathrm{X}$ & $\mathrm{X}$ & $\mathrm{X}$ \\
\hline Number of inhabitants & $\mathrm{X}$ & $\mathrm{X}$ & $\mathrm{X}$ & $\mathrm{X}$ & $\mathrm{X}$ \\
\hline Waste and organic matter types & $\mathrm{X}$ & $\mathrm{X}$ & $X$ & $\mathrm{X}$ & $X$ \\
\hline Wind & & & & & $\mathrm{X}$ \\
\hline
\end{tabular}

since the variable is directly related with the structural element 'humidity' and thus with a higher production of leachate and with the consequent risk of contamination.

$W_{j}$ also reaches a value of 2 when the variable directly affects the structural elements, although these may not directly be related to the environmental elements. For example, the variable 'distance from the population point' contemplates the distance between the landfill and the nearest population point, including isolated settlements, and affects the environmental element 'human health'. In this case, the weighting of the variable also obtains a value of 2 , since it is directly related to the risk of pollution to the health of the inhabitants of the population point [33].

Justification and classification of the variable 'distance from population points' is shown in Table 4. Classification is carried out on the basis of criteria established by research into congenital [34] and 
Table 3: Classification of variables taking into account location, design and operation of landfills.

\begin{tabular}{|c|c|c|}
\hline Variable & Location & Design and operation \\
\hline Settling of waste & & $X$ \\
\hline Aquifer characteristics & $X$ & \\
\hline Final covering & & $X$ \\
\hline Compaction & & $X$ \\
\hline Control of gas & & $\mathrm{X}$ \\
\hline Control of liquid leachate & & $X$ \\
\hline Distance from infrastructure & $\mathrm{X}$ & \\
\hline Distance from surface water mass & $\mathrm{X}$ & \\
\hline Distance from population points & $\mathrm{X}$ & \\
\hline Landfill age & & $X$ \\
\hline Erosion & $X$ & \\
\hline State of roads in the landfill & & $X$ \\
\hline Fault located in proximity to the landfill & $\mathrm{X}$ & \\
\hline Waterproofing of release vessel & & $X$ \\
\hline Covering material & $\mathrm{X}$ & $X$ \\
\hline Slope to surface water & $\mathrm{X}$ & \\
\hline Pluviometry & $\mathrm{X}$ & \\
\hline $\begin{array}{l}\text { Release point localisation in flood-water } \\
\text { storage volume }\end{array}$ & $\mathrm{X}$ & \\
\hline Release point localisation in surface runoff & $\mathrm{X}$ & \\
\hline Seismic risk & $\mathrm{X}$ & \\
\hline Safety & & $X$ \\
\hline Surface drainage systems & & $X$ \\
\hline Slopes of waste & & $X$ \\
\hline Number of inhabitants & $\mathrm{X}$ & $X$ \\
\hline Waste and organic matter types & & $X$ \\
\hline Wind & $X$ & \\
\hline
\end{tabular}

chromosomal [35] anomalies observed in people living near landfills, as well as a Spanish legislation concerning hazardous and insanitary activities [36] and other studies relating to the presence of low or high-density population zones near release points and their environmental impact [37, 38]. The same justification and quantification is applied to all the other variables and environmental elements.

Individual analysis of the CRIs obtained for each variable provides information concerning the actions that need to be carried out in the conditioning or closure plans. For example, it may be necessary to improve the control of leachates or biogas, or to construct facilities for the collection of surface runoff.

2.3.2 Probability of contamination due to landfill site and probability of contamination due to landfill operation

Taking into account the rate expression for probability of contamination for each environmental element, two further indexes are obtained. These provide information about the suitability of the location of the landfill and its operational state, and again apply to each environmental element: 
Table 4: Classification and weighting of the variable 'distance from population points' for the environmental element 'human health'.

\begin{tabular}{llcc}
\hline Condition & Justification & $\begin{array}{c}\text { Weighting } \\
\mathrm{W}_{j}\end{array}$ & $\begin{array}{c}\text { Classification } \\
\text { value } \mathrm{C}_{j}\end{array}$ \\
\hline Landfill very close & $\begin{array}{c}\text { High-density urban settlement at a } \\
\text { close distance (under 2 km) } \\
\text { Rural area with several developments } \\
\text { or an urban industrial area at a close } \\
\text { distance (under 2 km) }\end{array}$ & 2 & 5 \\
$\begin{array}{l}\text { Rural area with dispersed } \\
\text { developments at some distance } \\
\text { distance }\end{array}$ & 2 & 3 \\
Landfill far & $\begin{array}{l}\text { Fetw and dispersed constructions at } \\
\text { some distance (between 2 and 3 km) }\end{array}$ & 2 & 2 \\
Landfill very far & No developments in area (over 3 km) & 2 & 1 \\
\hline
\end{tabular}

'Probability of contamination due to landfill site' $\left(\mathrm{Pbc}-\mathrm{s}_{i}\right)$ and 'probability of contamination due to landfill operation' $\left(\mathrm{Pbc}-\mathrm{o}_{i}\right)$. The rate expression used to quantify these indexes is represented by eqn (4); however, variables included in this expression are restricted to those related to the location of the landfill in the first case, and those related to the operation of the landfill in the second case. The variables may obtain values between 0 and 1 and are classified as 'very high', 'high', 'average', 'low' and 'very low' (Table 1).

\subsection{Environmental value}

The concept, environmental value $(\mathrm{eV})$, is designed to identify and quantify the environmental assessment of each environmental element in the area of the landfill. It is considered as a relative environmental value, since it takes into account the relationship between the landfill environmental and/or social and political characteristics and the emissions in the release point [3], as well as the environmental importance for each element in the surroundings of the landfill. The $\mathrm{eV}$ provides information concerning the suitability of the landfill location. If an environmental element obtains high or very high values, it indicates that the landfill is located in an area of greater environmental sensitivity for the element in question.

Values range between 1 and 5 for each environmental element, with classifications of 'very high', 'high', 'average', 'low' and 'very low' (Table 1).

In the case of surface water, three characteristics are used to quantify the environmental value: the type of the surface water mass $\left(A_{1}\right)$, the use of water $\left(A_{2}\right)$, the existence of animal or vegetable species water quality $\left(A_{3}\right)$. The rate expression used to quantify these three characteristics is represented by eqn (5).

Table 5 shows the justification and quantification in the case of the characteristic 'use of water'. The same justification and quantification is applied to the other characteristics and environmental elements.

$$
\mathrm{eV}_{\text {surface water }}=\frac{A_{1}+A_{2}+A_{3}}{3} \text {. }
$$


Table 5: Justification and quantification of the characteristic 'use of water' for the environmental element 'surface water'.

\begin{tabular}{lll}
\hline$A_{2} \quad$ Use of water & 1 & Not for use by humans \\
& 2 & Hydroelectric, navigation and other uses \\
& 3 & Industrial \\
& 4 & Agriculture \\
& 5 & Human drinking water, aquaculture and recreational uses \\
& & including beaches suitable for bathing \\
\hline
\end{tabular}

Table 6: Landfill characteristics.

\begin{tabular}{ll}
\hline $\begin{array}{l}\text { Population served } \\
\text { Composition of } \\
\text { disposed waste }\end{array}$ & 1,200 habitants \\
Geology & Debris and some hazardous waste. \\
& Detrital sediments from marly rocks: limestones and dolomites \\
with karstic characteristics. \\
Natural site known as Sierra de Huétor, in a trough - middle \\
mountain - inclinations are between $10 \%$ and $15 \%$. High risk of \\
undermining release material. \\
Confluence of many courses from the surface runoff. \\
Surface hydrology & The aquifer is in a substrate composed mainly of marble and dolomites \\
Ground hydrology & from the Alpujarra mountains between the Subbetic and the \\
& Penibetic mountains. The substrate can be considered as permeable \\
& with the groundwater table at a depth of approximately 5 m. \\
Mild continental-Mediterranean climate. Between 1000 and \\
Climate & 1500 m high. Effective rain: $100-300$ mm. Low exposure \\
& to wind. \\
Soil uses & Sierra de Huétor Natural Park. \\
Biota & Pines and bushes. Fauna without peculiar characteristics. \\
Infrastructure & Access road not asphalted. Main road network at 600 m. \\
Population centres & Farther than 2.5 km.
\end{tabular}

\subsection{Description of landfills}

\section{METHODOLOGY APPLICATION}

Application of the methodology is based on the collection of data relating to the physical environment, state and characteristics of the release points. Data collection involved visiting the different landfills as well as studying existing information on the deposit points and the characteristics of their environment. The results from the data acquisition card used for one of the landfills studied (Huétor Sierra Natural Park) are summarised in Table 6. 


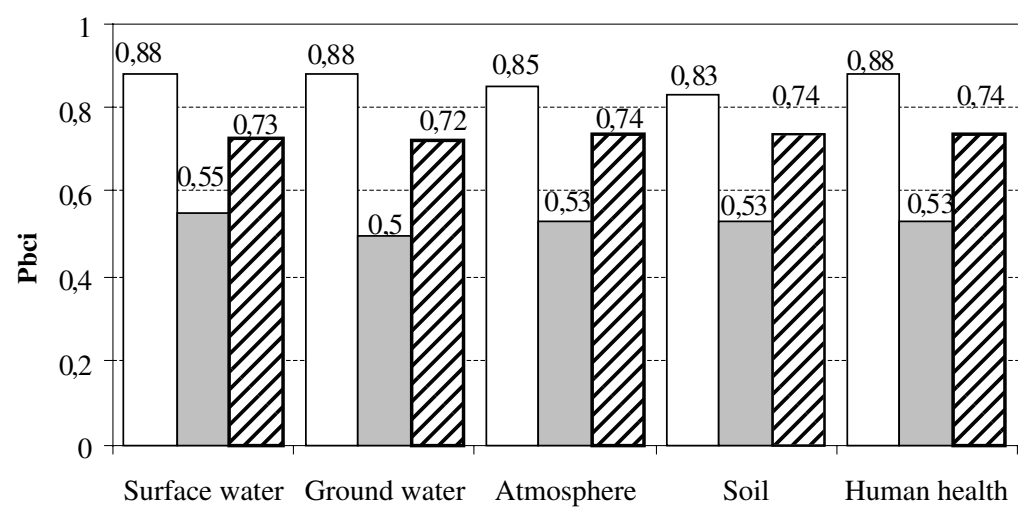

Environmental elements

$\square$ Pbc-o $\square$ Pbc-s $\square \mathrm{Pbc}$

Figure 1: Probability of contamination for each environmental element of studied release point.

\subsection{Results and discussion}

3.2.1 Suitability of the landfilling site

Waste disposed in a landfill is usually subject to a series of complex biochemical and physical processes, which generate environmental impacts. The significance of such impacts largely depends on the spatial distribution of the effects of the proposed action and the distribution of the affected receivers [39]. Accordingly, the first step in the environmental diagnosis of the release point, studied as an example (Huétor Sierra Natural Park), was to analyse the suitability of the site.

With the EVIAVE methodology, it was possible to analyse two indexes: the probability of contamination due to the landfill site and the environmental values for each environmental element.

Figure 1 shows the probability of contamination due to a landfill site for each environmental element (Pbc-s). In each case, the probability was classified as average. Whereas the variables in the probability of contamination take into account the biochemical and physical processes affecting the environmental elements, the landfill site must also take into account the social, technical and political parameters [40-42]. These were considered as part of the environmental value.

In the example studied, the release point was located in a natural park; so the environmental value was 5 (very high) for all the environmental elements in accordance with the guidelines of the European Council Directive on waste release [28].

\subsubsection{Suitability of landfill operation and design}

Suitable design and operation of the landfill are essential in order to eliminate or minimise associated adverse environmental impacts [7]. Indeed, the significance of environmental impacts is dependent on the operation and design of the landfills too.

To quantify the environmental impacts due to operation and design, the corresponding variables were analysed. Figure 1 shows the probability of contamination due to landfill operation $\left(\mathrm{Pbc}-\mathrm{O}_{i}\right)$. In this case, the index presented values classified as very high because the release point was uncontrolled. In effect, the operation was close to open-pit dumping, with consequent major adverse impacts [7]. 


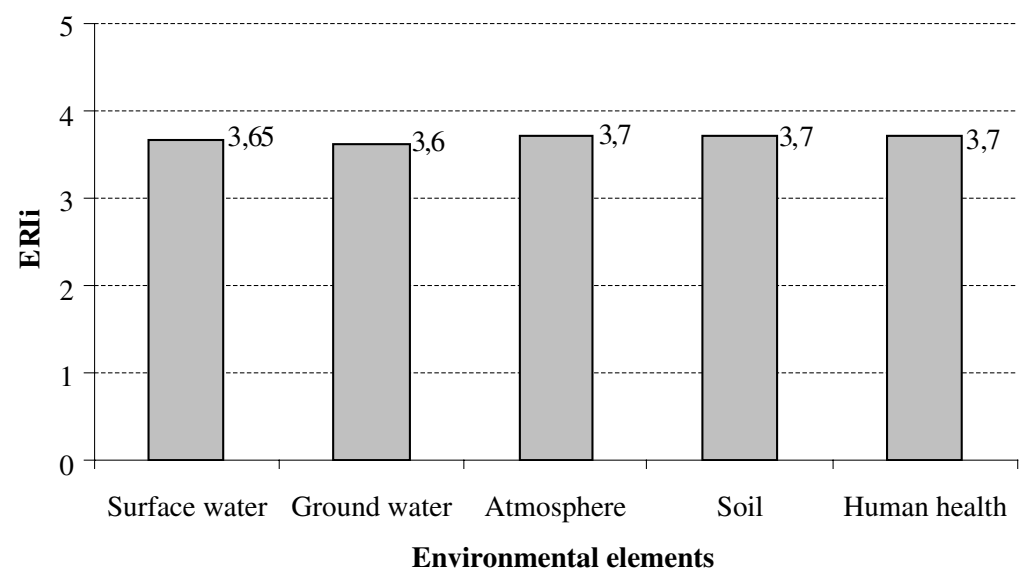

Figure 2: ERI for each environmental element of the studied release point.

\subsubsection{Probability of contamination}

Figure 1 also shows the global probability of contamination for each environmental element, taking into account landfill operation, design and siting. As may be observed, the values were high for each environmental element.

\subsubsection{Environmental Risk Index}

To determine the environmental impact of the release point, it is necessary to assess the probability of contamination of each environmental element due to interaction between the landfill and the environmental characteristics. However, it is also necessary to consider other legal, social and economic characteristics that likewise contribute to the environmental impact. These are considered as part of the environmental value. The ERI reflects the environmental impact for each environmental element, taking into account these considerations.

Figure 2 shows the ERI for each environmental element for the studied example. In this case, all the values were high, indicating that there was a high risk that the release point would affect each environmental element.

\subsubsection{Environmental landfill interaction index}

Finally, the global environmental impact of the landfill was quantified. The value obtained was 18.35 , corresponding to a classification of 'high'.

\subsubsection{Closing plan}

In view of the non-suitability of the release point location and the high ELI, it was necessary to draw up a closing plan to stop the disposal of waste in the studied release point and to design a sealing system to reduce the environmental impact as far as possible.

To draw up the closing plan, the CRI for each variable and for each environmental element was studied in order to determine the state of impact of each variable and to plan direct actions for those variables in which it was possible to reduce the environmental impact. Figure 3 shows the state of variables related to operation and design for surface water. In this case, the closing plan should specify actions such as construction of surface drainage systems, covering material, waterproofing of release vessel, control of liquid leachate and compaction, final covering and settling of waste. 


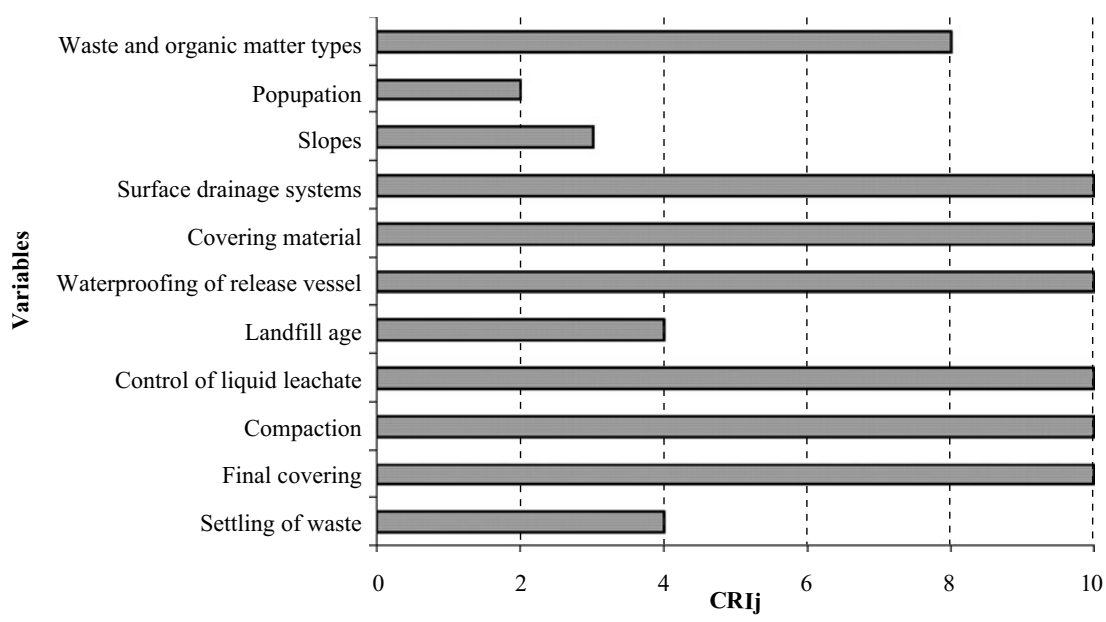

Figure 3: CRI for each variable of the environmental element 'surface water' in the studied release point.

A similar analysis was carried out for the remaining variables and the environmental elements.

\section{CONCLUSIONS}

The EVIAVE methodology makes it possible to carry out an environmental diagnosis of urban waste landfills by providing sufficient data to determine the set of environmental problems posed by each landfill. In the studied example, the environmental impact was quantified and classified as high, indicating the need to take measures to reduce the environmental impact as far as possible.

The results obtained from the methodology, formulated in a series of environmental indexes, may be used in various ways:

1. As a tool for studying the suitability of landfill sites and for monitoring their operation. In the example studied in this paper, the location of the landfill was shown to be unsuitable and its design and operation were inadequate.

2. For application in closing, sealing and conditioning projects in cases where termination of the landfill operation is required. Bearing in mind the unsuitable location of the studied release point and the high value of the ELI, it was concluded that the release point should cease operation and that a closing plan should be drawn up. The plan would include a sealing system designed to reduce the environmental impact as far as possible.

Applied to other release points in the area under study, the EVIAVE methodology would make it possible to draw up a list of priority actions and thus facilitate a co-ordinated process of planning and decision-making.

\section{ACKNOWLEDGEMENTS}

This research is part of an R\&D Project funded by the Spanish Ministry of Science and Technology entitled 'Design and implementation of methodologies for the environmental diagnosis of urban waste landfills and waste dumps' (TIC-2002-04330-C02-01). 


\section{REFERENCES}

[1] Diaz, L.F., Savage, G.M. \& Egerth, L.L., Alternatives for the treatment and disposal of healthcare wastes in developing countries. Waste Management, 6, pp. 626-637, 2005.

[2] Calvo, F., Moreno, B., Ramos, A. \& Zamorano, M., Implementation of a new environmental impact assessment for municipal waste landfill as tool for planning and decision-making process. Renewable and Suitable Energy Reviews, 2005, in press.

[3] Calvo, F., Moreno, B., Zamorano, M. \& Szanto, M., Environmental diagnosis methodology for municipal waste landfills. Waste Management, 25, pp. 768-779, 2005.

[4] Garrod, G. \& Willis, K., Estimating lost amenity due to landfill waste disposal. Resources, Conservation and Recycling, 22, pp. 83-95, 1998.

[5] Read, A.D., Philips, P. \& Robinson, G., Landfill as a future waste management option in England: the view of landfill operators. Resources, Conservation and Recycling, 20, pp. 183-205, 1997.

[6] Burford, C., The UK waste strategy. IWM Conference Proceedings, pp. 82-85, 1995.

[7] El-Fadel, M., Findikakis, A.N. \& Leckie, J.O., Environmental impacts of solid waste landfilling. Journal of Environmental Management, 50, pp. 1-25, 1997.

[8] Mato, R.R.A.M., Environmental implications involving the establishment of sanitary landfills in five municipalities in Tanzania: the case of Tanga municipality. Resources, Conservation and Recycling, 25, pp. 1-16, 1999.

[9] ISWA (International Solid Waste Association), 1000 Terms in Solid Waste Management, ed. J. Skitt, ISWA: Copenhagen, Denmark, 1992.

[10] Senior, E., Microbiology of Landfill Sites, CRC Press: Boca Raton, FL, 1990.

[11] Raybould, J.G. \& Anderson, D.J., Migration of landfill gas and its control - a case history. Journal of Engineering Geology, 20, pp. 75-83, 1987.

[12] Leone, I.A., Flower, F.B., Arthur, J.J. \& Gilman, E.F., Damage to woody species by anaerobic landfill gases. Journal of Arboriculture, 3, pp. 221-225, 1979.

[13] Gilman, E.F., Flower, F.B. \& Leone, I.A., Standardized procedures for planting vegetation on completed sanitary landfills. Waste Management \& Research, 3, pp. 65-80, 1985.

[14] Young, P.J. \& Heasman, L.A., An assessment of the odour and toxicity of the trace components of landfill gas. Proceedings of the GRCDA 8th International Landfill Gas Symposium, San Antonio, Texas, 1985.

[15] Deipser, A. \& Stegmann, R., Biological degradation of VCCs and CFCs under simulated anaerobic landfill conditions in laboratory test digesters. Environmental Science and Pollution Research, 4(4), pp. 209-216, 1997.

[16] Edgers, L., Noble, J.J. \& Williams, E., A biologic model for long term settlement in landfills. Proceedings of the Mediterranean Conference on Environmental Geotechnology, eds. M.A. Usmen \& Y.B. Acat., Cesme, Turkey, pp. 177-184, 1992.

[17] Wall, D.K. \& Zeiss, C., Municipal landfill biodegradation and settlement. Journal of Environmental Engineering, 121, pp. 214-224, 1995.

[18] Chofqi, A., Younsi, A., Lhadi, E.K., Mania, J., Mudry, J. \& Veron, A., Environmental impact of an urban landfill on a coastal aquifer (El Jadida, Morocco). Journal of African Earth Sciences, 39, pp. 509-516, 2004.

[19] Mendes, M.R., Aramaki, T. \& Hanaki, K., Comparison of the environmental impact of incineration and landfilling in Sao Paulo City as determined by LCA. Resources, Conservation and Recycling, 41, pp. 47-63, 2004.

[20] Nevenka, M., Bozena, C., Marijan, A., Svjetlana, A. \& Zdenkan, T., Assessment of groundwater contamination in the vicinity of a municipal solid waste landfill (Zagreb, Croatia). Water Science and Technology, 37(8), pp. 37-44, 1998. 
[21] Shen, T.T., Nelson, T.P. \& Schmidt, C.E., Assessment and control of VOC emissions from waste disposal facilities. CRC Critical Reviews in Environmental Control, 20, pp. 43-76, 1990.

[22] Pearce, F., Methane: the hidden greenhouse gas. New Scientist, 6, pp. 37-41, 1989.

[23] Meraz, R.L., Vidales, A.M. \& Domínguez, A., A fractal-like kinetics equation to calculate landfill methane production. Fuel, 83, pp. 73-80, 2004.

[24] Miroslav, N., Therrien, R., Lefebvre, R. \& Gélinas, P., Gas production and migration in landfill and geological materials. Journal of Contamination Hydrology, 52, pp. 187-211, 2001.

[25] Burnley, S., The impact of the European landfill directive on waste management in the United Kingdom. Resources, Conservation and Recycling, 32, pp. 349-358, 2001.

[26] Price, J.L., The landfill directive and the challenge ahead: demands and pressures on the UK householder. Resources, Conservation and Recycling, 32, pp. 333-348, 2001.

[27] Kettunen, M. \& Vuorisalo, T., History and development of Finnish landfill research: impacts of legislative changes and EC policies. Resources, Conservation and Recycling, 44, pp. 51-71, 2005.

[28] Council Directive 1999/31/EC of 26 April 1999 on the landfill of waste. Official Journal of the European Communities, L182, pp. 1-19, 16 July 1999.

[29] Conesa, V., Instrumentos de la gestión ambiental en la empresa (Instruments for environmental management in companies). Mundi Prensa Libros S.A.: Madrid, 1997.

[30] Carter, L., Ward, C.H., Ginger, W. \& McCarty, P.L., Methods for assessment of groundwater pollution potential, John Wiley \& Sons: New York, 1997.

[31] Al-Yaqout, A.F., Koushki, P.A. \& Hamoda, M.F., Public opinion and siting solid waste landfills in Kuwait. Resources. Conservation and Recycling, 35, pp. 215-227, 2002.

[32] Moya, J., López, J.A., Rubio, J.C., Beas, J., Gallardo, V. \& Alcaín, G., Censo de vertederos incontrolados de la Provincia de Granada y orientaciones al sellado [Census of uncontrolled waste disposal sites in the Province of Granada, with guidelines for sealing], Diputación de Granada [Granada Provincial Government] - ITGE, 2001.

[33] Calvo, F., Metodología de diagnóstico y caracterización ambiental de vertederos de residuos sólidos urbanos para su control, cierre, sellado y reinserción [Methodology for the diagnosis and environmental characterization of urban solid waste disposal sites, with a view to their control, closure, sealing and restoration], Doctoral Thesis, University of Granada, Spain, 2003.

[34] Geschwind, S.A., Stolwijk, J.A., Bracken, M., Fitzgerald, E., Stark, A., Olsen, C. \& Melius, J. Risk of congenital malformations associated with proximity to hazardous waste sites. American Journal of Epidemiology, 135(11), pp. 1197-1207, 1992.

[35] Kontos, T.D., Komilis, D.P. \& Halvadakis, C.P. Siting MSW landfills with a spatial multiple criteria analysis methodology. Waste Management, 25(8), pp. 818-832, 2005.

[36] BOE (Official Bulletin of Spain) no. 292, Decreto 2414/1961, de 30 de noviembre, por el que se aprueba el Reglamento de actividades molestas, insalubres, nocivas y peligrosas [Decree 2414/1961, 30th November: approval of Regulation governing hazardous, insanitary, harmful and dangerous activities], 7 December 1961.

[37] Dolk, H., Vrijheid, M., Armstrong, B., Abramsky, L., Bianchi, F., Garne, E., Nelen, V., Robert, E., Scott, J.E.S., Stone, D. \& Tenconi, R. Risk of congenital anomalies near hazardous-waste landfill sites in Europe: the EUROHAZCON study. The Lancet, 352(9126), pp. 423-428, 1998.

[38] Laguna, M., Romero-Schmidt, H. \& Ortega-Rubio, A., Solid waste management in the Baja California peninsula. Waste Management and the Environment. International Conference on Waste Management and the Environment, WITpress: Southampton \& Boston, pp. 81-88, 2002. 
[39] Antunes, P., Santos, R. \& Jordâo, L. The application of Geographical Information System to determine environmental impact significance. Environmental Impact Assessment Review, 21, pp. 511-535, 2001.

[40] Leat, J. \& Rodríguez, E., Guías para la evaluación del impacto ambiental de proyectos de desarrollo local [Guides for environmental impact assessment in projects for local development], Instituto Latinoamericano y del Caribe de Planificación Económica y Social (ILPES), Santiago de Chile, 1998.

[41] Gómez, D., Evaluación de impacto ambiental [Environmental Impact Assessment]. Ediciones Mundic-Prensa. (Editorial), Agrícola Española, S.A., Madrid, 1999.

[42] Montos, T.D., Komilis, D.P. \& Halvadakis, C.P., Siting MSW landfills with a spatial multiple criteria analysis methodology. Waste Management, 25, pp. 818-832, 2001. 